\title{
Axons of Early Generated Neurons in Cingulate Cortex Pioneer the Corpus Callosum
}

\author{
Susan E. Koester and Dennis D. M. O'Leary \\ Molecular Neurobiology Laboratory, The Salk Institute, La Jolla, California 92037
}

The internal capsule and corpus callosum are the two major efferent axonal pathways of the mammalian neocortex. Previous studies have shown that the first cortical axons to grow through the internal capsule, the pathway from cortex to its subcortical targets, are extended by subplate neurons, which are the earliest generated neurons in the neocortex. Here, we characterize the origin of the first axons to project through the other major efferent pathway of the cortex, the midline corpus callosum, which connects the two cortical hemispheres. Using anterograde Dil tracing, we show that cortical axons first cross the midline through the nascent corpus callosum at E17. Retrograde Dil labeling from medial cortex at $E 18$ reveals that these axons originate from a discrete group of neurons in medial (presumptive cingulate) cortex. These early callosal cells have complex morphologies with highly branched dendrites and later appear to take on a pyramidal form characteristic of callosal neurons in deep layers of cingulate cortex. ${ }^{3} \mathrm{H}$-thymidine birthdating demonstrates that these cells are predominantly generated on E14, making them among the earliest generated neurons in this cortical region. Injections of retrograde tracers in one cortical hemisphere at late embryonic or early postnatal ages result in substantial numbers of neurons labeled in the ipsilateral subplate, but only a few neurons labeled in the contralateral subplate. Thus, subplate neurons do not pioneer or ever project in significant numbers through the corpus callosum. We conclude that the two major efferent pathways from cortex, the corpus callosum and the internal capsule, are pioneered by developmentally and spatially distinct populations of early generated cortical neurons.

[Key words: axonal guidance, axonal pathfinding, cortical development, cortical neurogenesis, pioneer neurons, subplate]

The two major efferent axonal pathways from the mammalian cortex are the callosal, through the corpus callosum, and the subcortical, through the internal capsule. The callosal projection arises from neurons in five of the six main cortical layers, the

\footnotetext{
Received Feb. 9, 1994; revised Apr. 19, 1994; accepted Apr. 27, 1994.

We thank Dr. Joel Price for helpful discussions and Dr. Pat Levitt for comments on the manuscript. This work was funded by NIH Grant NS31158 and the Valley Foundation. Partial support for S.E.K. was derived from an Olin Fellowship administered through Washington University.

Correspondence should be addressed to Dennis D. M. O'Leary, Molecular Neurobiology Laboratory, The Salk Institute, 10010 North Torrey Pines Road, La Jolla, CA 92037.

Copyright (C) 1994 Society for Neuroscience $0270-6474 / 94 / 146608-13 \$ 05.00 / 0$
}

exception being the neuron-sparse layer 1 (Wise and Jones, 1976). Subcortical projections originate exclusively from the deep cortical layers; layer 6 neurons project to the thalamus, while layer 5 neurons project to the midbrain, hindbrain, and spinal cord (Wise and Jones, 1977). In addition, subcortically and callosally projecting ncurons arc found in cingulate cortex, which is positioned next to the midline just medial to the neocortex, and perirhinal cortex, which is positioned ventrolateral to the neocortex. In both adult (Miller, 1975; Catsman-Berrevoets et al., 1980; Swadlow and Weyand, 1981; Wong and Kelly, 1981) and developing animals (Koester and O'Leary, 1993), subcortical and callosal projections are formed by completely separate populations of neurons.

Pioneer neurons have been defined as those that extend the first axons through a pathway (Bate, 1976; Bentley and Keshishian, 1982). Neurons of the neocortical subplate send the first axons from cortex into the internal capsule, and thus "pioneer" this pathway (McConnell et al., 1989; Blakemore and Molnar, 1990; De Carlos and O'Leary, 1992; Erzurumlu and Jhaveri, 1992). Subplate cells are the earliest generated population of cortical neurons. Upon becoming postmitotic, these neurons aggregate bencath the pial surfacc, dircetly over the neuroepithelium, to form the preplate. Subsequently, neurons of the cortical plate proper are generated, migrate from the neuroepithelium, and aggregate within the preplate, splitting it into a deep, neuron-rich subplate and a superficial neuron-poor marginal zone or layer 1 (Marin-Padilla, 1978; Luskin and Shatz, 1985a). Cortical plate neurons are generated in an inside-out fashion such that the earliest generated cells are positioned deepest (Angevine and Sidman, 1961; Rakic, 1974; Luskin and Shatz, $1985 \mathrm{~b}$ ). This inside-out radial neurogenetic gradient is followed then by a morphogenetic gradient; subplate neurons are the first cortical cells to extend axons and layers 6 through 2 of the cortical plate differentiate in a deep to superficial gradient.

In this study, we set out to determine the nature of the neurons that pioneer the callosal pathway. Since in neonatal ferrets and cats neocortical subplate cells can be retrogradely labeled from contralateral cortex (Chun et al., 1987; Antonini and Shatz, 1990), it was reasonable to assume that subplate cells pioneer the corpus callosum as they do the internal capsule. We find, however, that the callosal pioneers are a distinct neuronal population clustered in the most ventromedial part of the nascent cingulate cortex. Using ${ }^{3} \mathrm{H}$-thymidine birthdating, we show that the callosal pioneers are predominantly generated on E14, making them among the earliest generated neurons in cingulate cortex (Richter and Kranz, 1979; Bayer, 1990b). Although previous reports have suggested that cingulate cortex lacks a defined subplate (Bayer, 1990a), we find that cells with the appropriate 
location and morphology for subplate cells are present in this region. However, in contrast to our preliminary report of these findings (Koester and O'Leary, 1991), our evidence suggests most, if not all, of the callosal pioneering neurons are not part of the cingulate subplate, but reside in the cortical plate and later develop pyramidal morphologies.

\section{Materials and Methods}

Animals. The fetuses and pups of timed-pregnant Sprague-Dawley rats (Harlan) were used. The day of insemination is designated embryonic day (E) 0. Pups were born on E22. The first $24 \mathrm{hr}$ after birth are designated postnatal day $(\mathrm{P}) 0$

Neuronal labeling. To examine the early development of the corpus callosum, we used postmortem DiI labeling in aldehyde fixed brains (Godement et al., 1987; Honig and Hume, 1989). When used in aldehyde-fixed tissue, 1,1'-dioctadecyl-3,3,3',3'-tetramethylindocarbocyanine perchlorate (DiI; Molecular Probes) applied to axons labels neurons in their entirety. DiI used as an anterograde tracer reveals the full extent of axons, including their collateral branches and growth cones. Dil used as a retrograde tracer reveals the complete dendritic morphologies of the labeled neurons. Fetuses were removed from anesthetized dams $(3.5 \%$ chloral hydrate in distilled water; $35 \mathrm{mg} / 100 \mathrm{gm}$ maternal weight) by cesarian section between noon and 3 P.M. on the stated embryonic day. Fetuses or postnatal pups were anesthetized with hypothermia and perfused transcardially with $10 \%$ formalin buffered to pH 7.4 with 0.1 m sodium phosphate buffer (10\% NBF). After $24 \mathrm{hr}$ postfixation, DiI ( $0.2 \%$ in dimethylformamide) was injected through a glass micropipette attached to a picospritzer (General Valve Corp.) into various sites in cortex. To label anterogradely the early callosal axons, Dil was injected into dorsomedial cortex. To label retrogradely the neurons giving rise to these axons, the rostral pole of one hemisphere of cortex was removed and DiI was injected into the exposed medial wall of the cortex. The injected brains were stored in $0.1 \mathrm{~m}$ sodium phosphate buffer in the dark for 2 weeks or longer. Brains were sectioned at $100-150 \mu \mathrm{m}$ on a vibratome. Sections were counterstained with bisbenzimide $(0.002 \%$ in sodium phosphate buffer; Sigma) and examined and photographed using a fluorescence microscope with rhodamine (DiI) or UV (bisbenzimide) illumination. Some DiI-labeled cells were photoconverted with DAB using the protocol of Sandell and Masland (1988).

The retrograde tracers fast blue (FB; Illing; $2 \%$ in distilled water), diamidino yellow (DY; Illing; $2 \%$ in distilled water), or rhodaminelabeled latex beads (RB; Lumafluor; diluted 1:4 in distilled water) were injected into the cortex of $\mathrm{P} 0$ pups through a pulled glass micropipette attached to a picospritzer. On P3, the pups were anesthetized using hypothermia and perfused transcardially with $10 \%$ NBF. The brains were removed, postfixed overnight, cryoprotected in $20 \%$ sucrose, and coronally sectioned at $40 \mu \mathrm{m}$ on a freezing microtome. Every other section was mounted on gelatin-subbed slides, dehydrated through ethanols, cleared in xylenes, coverslipped in Krystalon (Harleco), and examined with a fluorescence microscope using UV (FB, DY) illumination. Sections from brains containing RB were air dried on gelatincoated slides, coverslipped in $90 \%$ glycerol with $5 \% n$-propyl-gallate, and examined with rhodamine illumination. In each case, the alternate series of sections was mounted, counterstained with thionin, dehydrated, cleared, and coverslipped in DPX.

${ }^{3} \mathrm{H}$-thymidine birthdating. ${ }^{3} \mathrm{H}$-thymidine $\left({ }^{3} \mathrm{H}-\mathrm{TdR}\right)$ was used to birthdate the early callosal neurons identified by retrograde DiI labeling in fixed E1 8 brains. Dams were given either a single intraperitoneal injection of ${ }^{3} \mathrm{H}-\mathrm{TdR}(1 \mathrm{mCi} / 100 \mathrm{gm}$ maternal weight per injection) on $\mathrm{E} 12(n=2), \mathrm{E} 14(n=1)$, or E15 $(n=2)$, or two injections, one on E14 and one on E15 $(n=1)$. Two other dams received a series of six smaller doses (each being $0.33 \mathrm{mCi} / 100 \mathrm{gm}$ maternal body weight) at $8 \mathrm{hr}$ intervals over E13 and E14. The fetuses in one uterine horn were removed on E18 by cesarian section, perfused transcardially with $10 \%$ $\mathrm{NBF}$, and injected with DiI in medial cortex to label retrogradely the earliest callosal neurons. After DiI diffusion, brains were vibratome sectioned at $100 \mu \mathrm{m}$ and DiI labeled, and callosally projecting neurons were photoconverted with DAB. The vibratome sections were embedded in Durcupan (EM Sciences) and sectioned at $1.5 \mu \mathrm{m}$ on an ultramicrotome to ensure that all ${ }^{3} \mathrm{H}$ labeling could be detected, as the pathlength of the $\beta$-emission particle from ${ }^{3} \mathrm{H}$ decay is $2-3 \mu \mathrm{m}$ in tissue (Rogers, 1979). The semithin plastic sections were mounted on gelatincoated slides and dipped in NTB2 emulsion (Kodak) for ${ }^{3} \mathrm{H}$ autora-
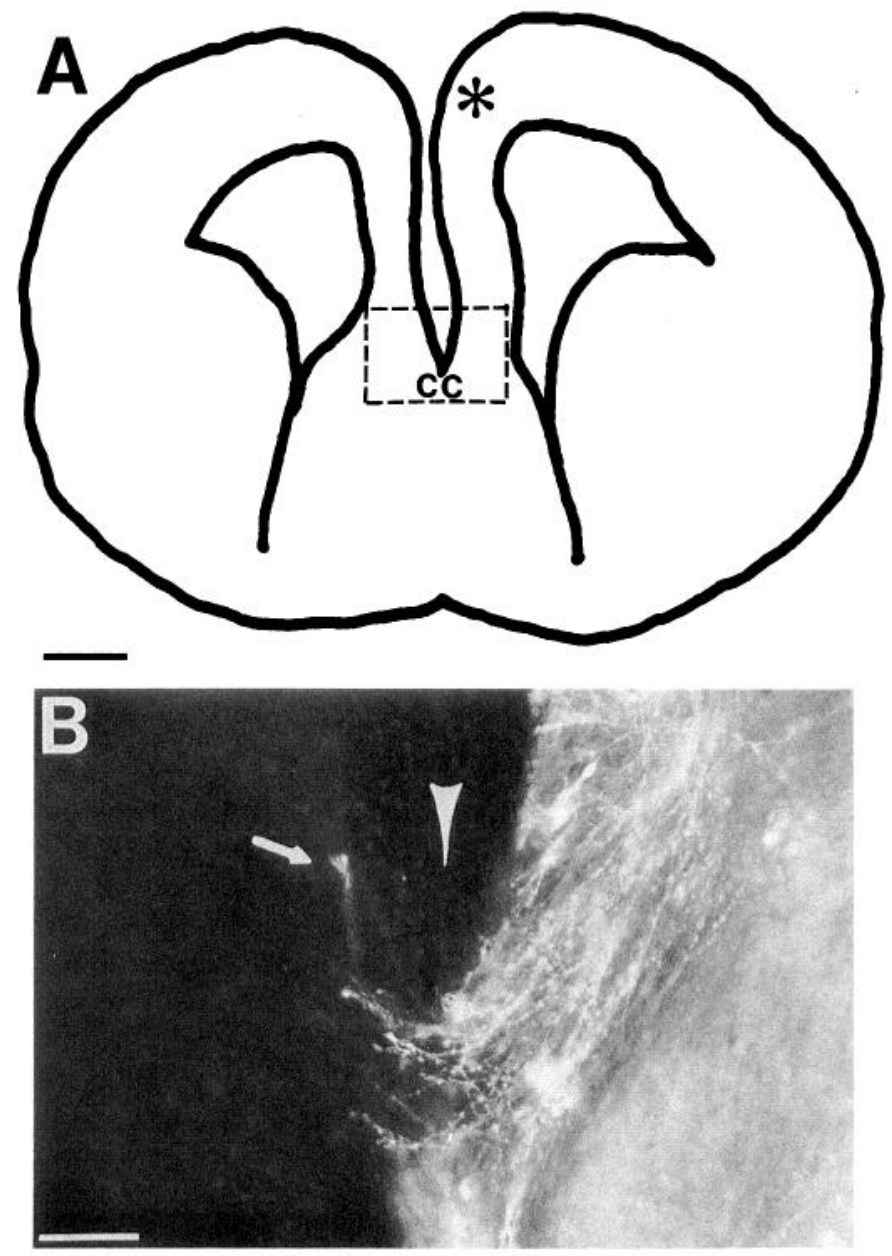

Figure 1. Cortical axons first cross the midline of the corpus callosum on E17. A, Outline of a coronal section through an E17 brain to show the approximate location of $B$ (dashed line). The location of the injection site is marked (asterisk). $c c$, corpus callosum primordium. B, A small number of axons, many tipped by growth cones, have reached the midline (arrowhead) at this stage. One (arrow) has begun to extend dorsally in the contralateral white matter. Scale bars: $A, 500 \mu \mathrm{m} ; B, 100 \mu \mathrm{m}$.

diography (Cowan et al., 1972). After a 6 week exposure, the slides were developed in D19 (Kodak), dehydrated through graded ethanols, cleared in xylenes, and coverslipped in DPX. The number of silver grains over every photoconverted DiI-labeled neuronal profile was counted and compared to background levels. A background level was determined for each slide by counting the number of grains over a region of known area on the slide and dividing by the ratio of that area to the average area of the neuronal nuclei. Background was very low, typically 0.2 grains/nuclear area. Profiles with two or more silver grains/nucleus were considered to be labeled. Profiles were categorized as heavily labeled if they contained more than $25 \%$ of the number of silver grains over the average of five of the most heavily labeled nuclei in that section. Labeled profiles with fewer than $25 \%$ of the number of silver grains over the most heavily labeled nuclei in that section were categorized as lightly labeled.

To determine the eventual laminar distribution of cells generated at the time of the ${ }^{3} \mathrm{H}-\mathrm{TdR}$ injection, fetuses in the intact uterine horn in the ${ }^{3} \mathrm{H}-\mathrm{TdR}$-injected dams were delivered normally and perfused between P0 and P21. The brains were cryoprotected in sucrose and sectioned at $40 \mu \mathrm{m}$ using a freezing microtome. A 1 -in-5 series of sections was mounted on gelatin-subbed slides, defatted in chloroform-ethanol (1:1), and dipped in NTB2 emulsion for ${ }^{3} \mathrm{H}$ autoradiography. The slides were exposed for 6 weeks, developed in D19, counterstained with thionin, dehydrated, cleared, and coverslipped in DPX. The laminar distributions of heavily labeled cells for each of the ${ }^{3} \mathrm{H}-\mathrm{TdR}$ injection protocols were qualitatively determined. 

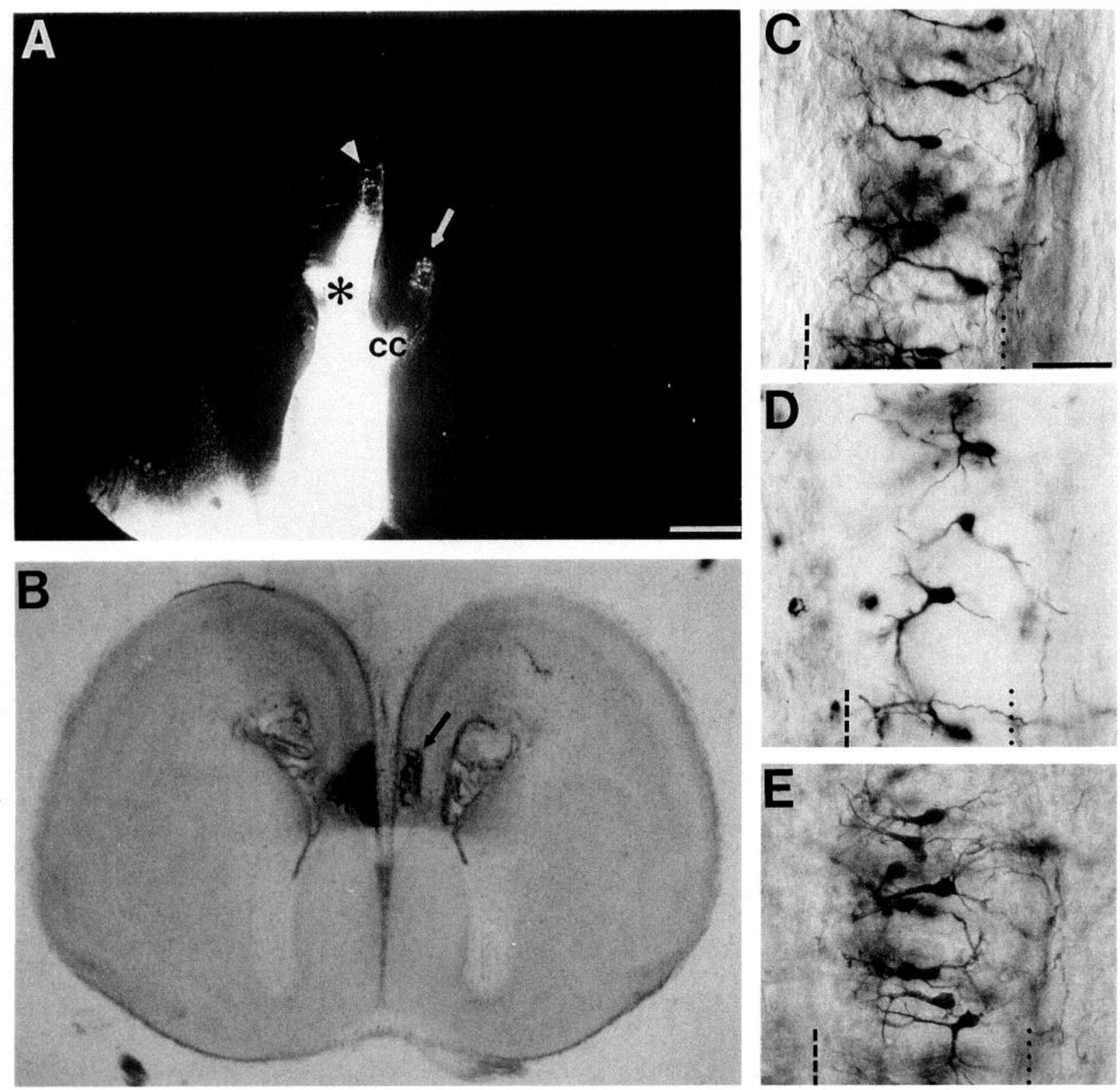

Figure 2. A discrete cluster of neurons in cingulate cortex pioneer the corpus callosum. The neurons giving rise to the early crossing axons are retrogradely labeled by a large injection in the contralateral white matter underlying medial cortex. $A$, Low-magnification fluorescence photomicrograph showing the location of the injection site (asterisk) and retrogradely labeled neurons (arrow) in a coronal section at E18. Ipsilateral to the injection site, retrogradely labeled cells are found only in medial cortex (arrowhead). $B, A$ similar field after DAB photoconversion. $C-E$, Typical morphologies of photoconverted callosal cells from the presumptive cingulate cortex at E18. The boundaries of the pia and intermediate zone are marked by dashed and dotted lines, respectively. Horizontal sections through brains of E18 rat fetuses show that the early callosal pathway is U-shaped, such that axons from rostral cortical regions cross the midline at a more caudal position and then extend rostrally in the contralateral hemisphere (Valentino and Jones, 1982). Therefore, as seen in $B$, the retrogradely labeled callosal pioneer neurons can be located rostral to the crossing point of the corpus callosum. Scale bars: $A$ and $B, 500 \mu \mathrm{m} ; C-E, 500 \mu \mathrm{m}$.

\section{Results}

\section{Identification of callosal pioneers}

The early development of the corpus callosum was examined with the postmortem method of Dil labeling in aldehyde fixed brains (Godement et al., 1987). Large DiI injections in dorsomedial cortex first anterogradely label axons crossing the midline on E17 (Fig. 1; $n=6$ ). The few axons that have crossed the midline do not yet extend any appreciable distance into contralateral cortex; therefore, these injections did not retrogradely label cortical cells contralateral to the injection.
To determine the origin of the earliest crossing axons, rat fetuses were perfused at E18 and large DiI injections were made in dorsomedial cortex $(n=9)$. At this age, a sizeable number of labeled axons have crossed the midline and many extend along the medial bank of the contralateral cortical wall. Cells retrogradely labeled at E18 in the hemisphere contralateral to the injection were restricted to a discrete cluster in ventromedial cingulate cortex (two examples are shown in Fig. $2 A, B$ ). Most of these cells are located in a cell-dense layer superficial to the cell-sparse intermediate zone. These cells have complex morphologies with extensively branched dendritic trees that typi- 

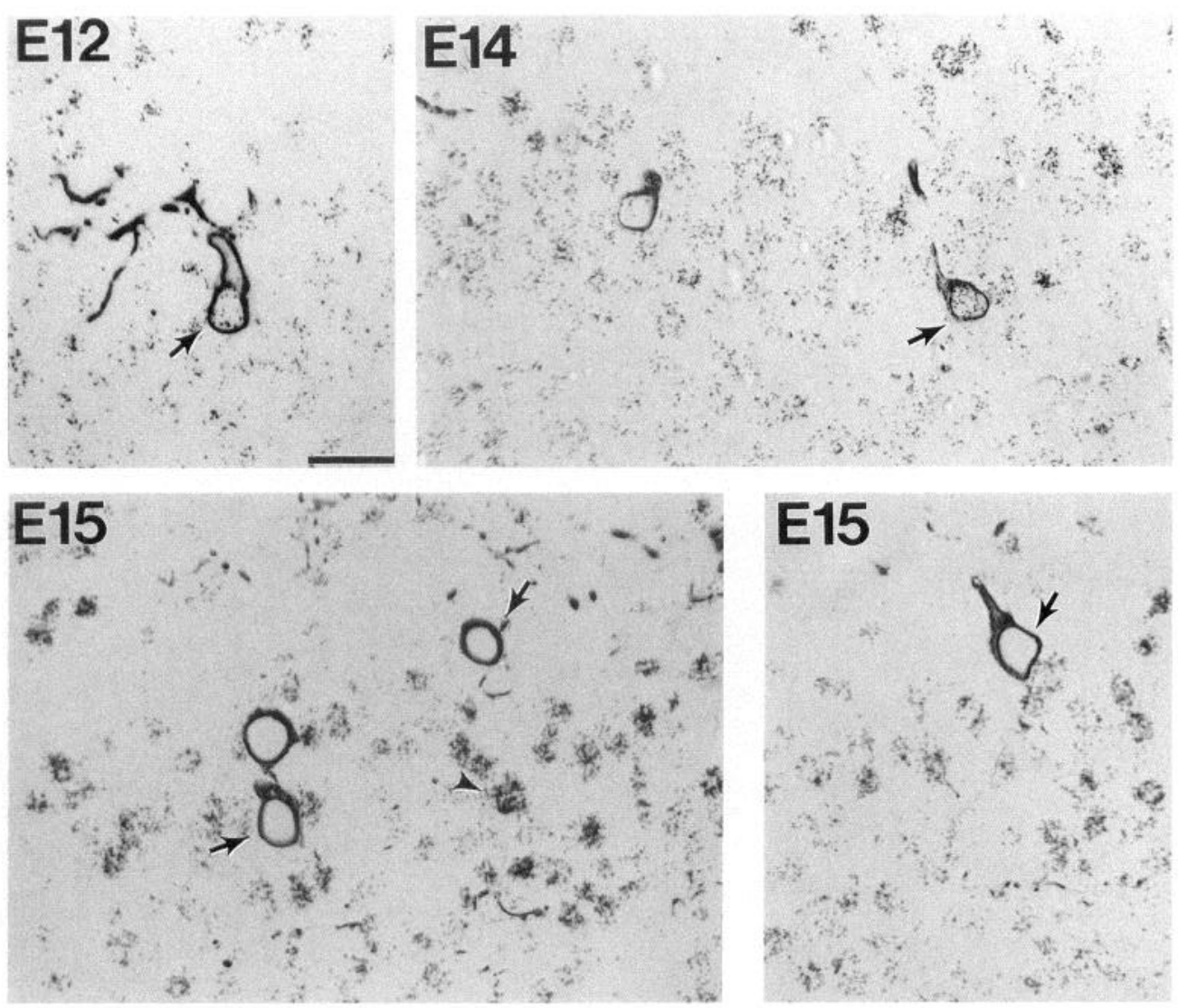

Figure 3. ${ }^{3} \mathrm{H}-\mathrm{TdR}$ birthdating of DAB photoconverted DiI-labeled cingulate callosal pioneer neurons. Dates given are those on which the ${ }^{3} \mathrm{H}-\mathrm{TdR}$ injection was given. Each case shown was sacrificed and DiI labeled on E18. Following ${ }^{3} \mathrm{H}-\mathrm{TdR}$ injections on $E 15$, DiIlabeled profiles are unlabeled (arrows) while large numbers of nuclei in the same region are heavily labeled (arrowhead). With an injection on E12, neither DiI-labeled (arrow) nor unlabeled neurons are heavily labeled by ${ }^{3} \mathrm{H}-\mathrm{TdR}$. An injection on EI4 results in large numbers of heavily ${ }^{3} \mathrm{H}-\mathrm{TdR}$-labeled, DiI-labeled neurons (arrow). Scale bar, $20 \mu \mathrm{m}$.

cally extend superficially into the marginal zone beneath the pial surface (Fig. $2 C-E$ ). Axons emerge from the labeled cells, descend into the intermediate zone, turn abruptly, and extend ventromedially to the midline. Thus, a discrete population of neurons in cingulate cortex pioneer the corpus callosum.

At E18, cortical cells retrogradely labeled ipsilateral to the DiI injections are also limited to cingulate cortex (Fig. $2 A$ ), although their tangential distribution extends farther dorsolaterally than that of cells labeled in cingulate cortex contralateral to the injections. This observation indicates that the axons of callosal neurons in the neocortex have yet to approach the midline as late as E18.

\section{Birthdates of callosal pioneer neurons}

Previous birthdating studies have shown that neurogenesis in cingulate cortex occurs between E13 and E20 (Richter and Kranz, 1979; Bayer, 1990b). E14, though, is the first day of appreciable neurogenesis, with only a very small percentage of cingulate neurons (roughly 1\%) generated on E13. With these data in mind, we gave ${ }^{3} \mathrm{H}-\mathrm{TdR}$ injections at various ages to determine when the early callosal neurons are generated. About half of the fetuses in each ${ }^{3} \mathrm{H}-\mathrm{TdR}$-injected dam were perfused at E18, and DiI was injected into the opposite cortical hemisphere to label retrogradely the early callosal neurons; the remaining fetuses were delivered normally and perfused between $\mathrm{P} 0$ and $\mathrm{P} 21$. The laminar distribution of the ${ }^{3} \mathrm{H}-\mathrm{TdR}$-labeled cells in these more mature littermates was appropriate for the time of injection (Berry and Rogers, 1965; Bruckner et al., 1976; Lund and Mustari, 1977; Richter and Kranz, 1979; Bayer, 1990b), confirming the gestational age at which the ${ }^{3} \mathrm{H}-\mathrm{TdR}$ was administered (data not shown).
The DiI labeling of the early callosal neurons in the E18 brains was photoconverted; the sections were embedded in plastic, resectioned at $1.5 \mu \mathrm{m}$, and processed for autoradiography. Figure 3 shows examples of cells singly or doubly labeled with DiI and ${ }^{3} \mathrm{H}-\mathrm{TdR}$ in the E18 brains. Reaction product deposited in the cell membranes due to DiI photoconversion with DAB outlines the retrogradely labeled, early callosal neurons; the nuclei are free of this reaction product, allowing for clear visualization of silver grains indicative of ${ }^{3} \mathrm{H}-\mathrm{TdR}$ labeling. Silver grains are located in clusters, delineating cell nuclei. Silver grains were typically found over DiI-labeled profiles in cases in which ${ }^{3} \mathrm{H}$ TdR was administered on E14 or earlier, but were almost never found over DiI-labeled profiles when the ${ }^{3} \mathrm{H}-\mathrm{TdR}$ was injected on E15.

Quantification of the ${ }^{3} \mathrm{H}-\mathrm{TdR}$ labeling of the DiI-labeled cell profiles is presented in two ways. In Figure 4 we have plotted the percentage of DiI-labeled profiles for each possible ${ }^{3} \mathrm{H}$ labeling index. Figure 5 shows the percentages of DiI profiles defined as heavily labeled, lightly labeled, or unlabeled with ${ }^{3} \mathrm{H}-$ $\mathrm{TdR}$ (see Materials and Methods). Although an injection of ${ }^{3} \mathrm{H}-$ $\mathrm{TdR}$ on E15 resulted in many heavily labeled nuclei in cingulate cortex ( $n=2$ brains), most DiI-labeled profiles were not labeled above background levels. In contrast, injections of ${ }^{3} \mathrm{H}$-TdR on E14 resulted in a high percentage of DiI-labeled profiles also labeled with ${ }^{3} \mathrm{H}-\mathrm{TdR}$ ( $n=2$ brains). The finding that virtually all DiI-labeled profiles were ${ }^{3} \mathrm{H}$ labeled by injections on $\mathrm{E} 14$ but almost none ${ }^{3} \mathrm{H}$ labeled by injections on E15 indicate that the DiI-labeled cells are synthesizing DNA on E14 but not on E15. To corroborate this inference, we gave multiple ${ }^{3} \mathrm{H}-\mathrm{TdR}$ injections on E13 and E14 or on E14 and E15. As expected, compared to cases with a single injection of ${ }^{3} \mathrm{H}$-TdR injections on 14 , a 


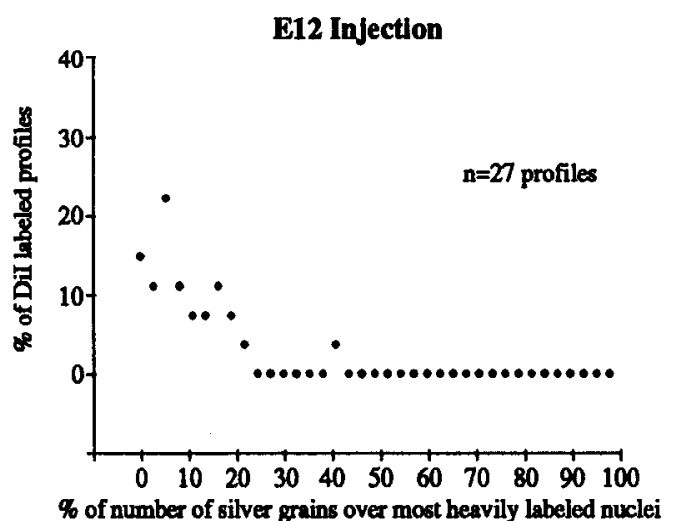

\% of number of silver grains over most heavily labeled nuclei
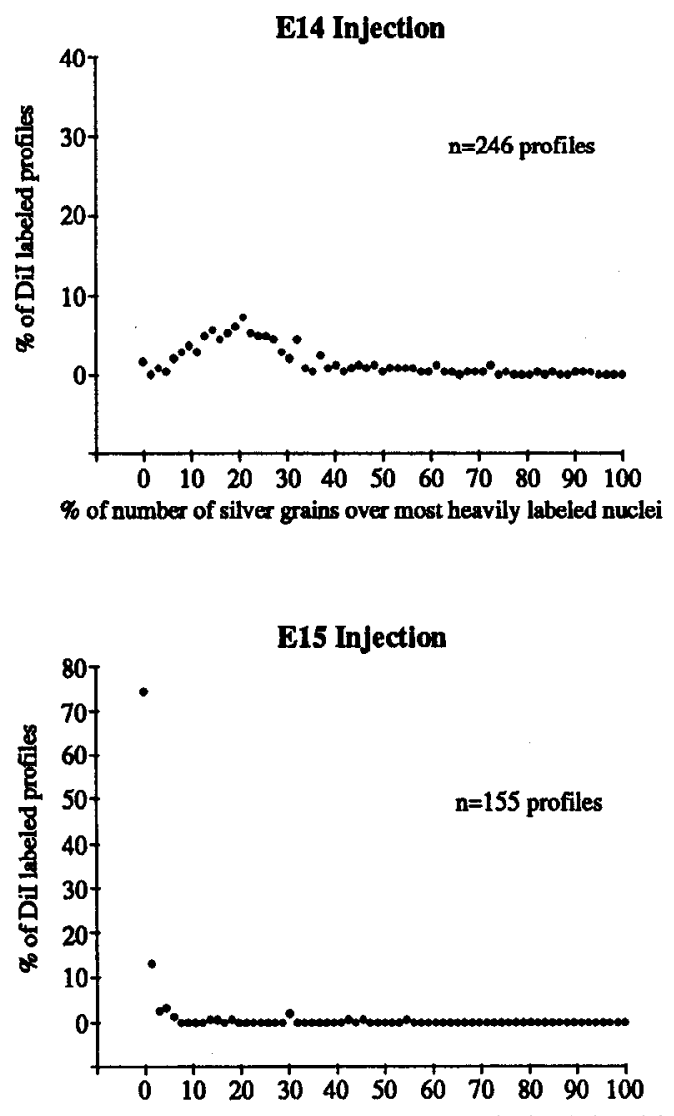

Figure 4. Quantification of ${ }^{3} \mathrm{H}-\mathrm{TdR}$ labeling of DAB photoconverted DiI-labeled cingulate callosal pioneer neurons. For each plot, the age(s) at which the ${ }^{3} \mathrm{H}$-TdR was administered is given. The $y$-axes represent the percentage of DiI-labeled profiles of the total number of DiI-labeled profiles. The $x$-axes represent the ${ }^{3} \mathrm{H}$ labeling index, which is expressed as a percentage and defined as the ratio of the number of silver grains over a DiIlabeled profile to the number of silver grains over the most heavily ${ }^{3} \mathrm{H}$-labeled cells in the same section. The DiI-labeled profiles were binned and plotted for each integer number of silver grains (i.e., profiles with one silver grain, profiles with two silvers grains, profiles with three silver grains, etc.) up to the number of grains over the most heavily ${ }^{3} \mathrm{H}$-labeled cells in the section (i.e., $100 \%{ }^{3} \mathrm{H}$ labeling index).

much higher percentage of DiI-labeled cells are heavily labeled in the E13/14 cases ( $n=2$ brains), whereas the percentage of heavily labeled neurons in the E14/15 cases ( $n=2$ brains) did not increase appreciably. Finally, injections of ${ }^{3} \mathrm{H}-\mathrm{TdR}$ on E12 resulted in few heavily labeled cells in cingulate cortex $(n=1$ brain), consistent with previous data that indicate that cells in this region undergo additional rounds of cell division after E12 (Richter and Kranz, 1979; Bayer, 1990b). (Since the number of silver grains over the most heavily labeled nuclei in these sections was low, number of cells scored as heavily labeled in cases
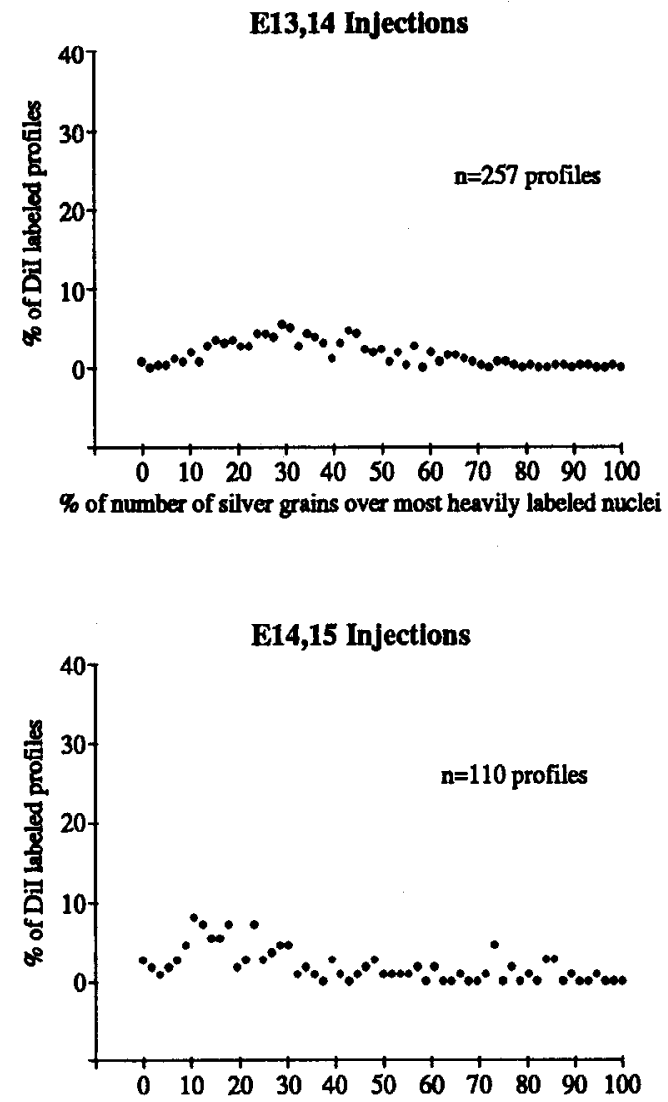

$\%$ of number of silver grains over most heavily labeled nuclei with $\mathrm{E} 12{ }^{3} \mathrm{H}-\mathrm{TdR}$ injections is artificially high.) In sum, these data indicate that the early callosal neurons are generated predominantly on E14, placing them among the earliest generated cells in cingulate cortex.

\section{Contribution of the neocortical subplate to the callosal projection}

To determine the contribution of neocortical subplate cells to the callosal projection, we examined sections of cortex (Fig. 6 A) contralateral to injections of DY, FB, or RB made in the cortical 

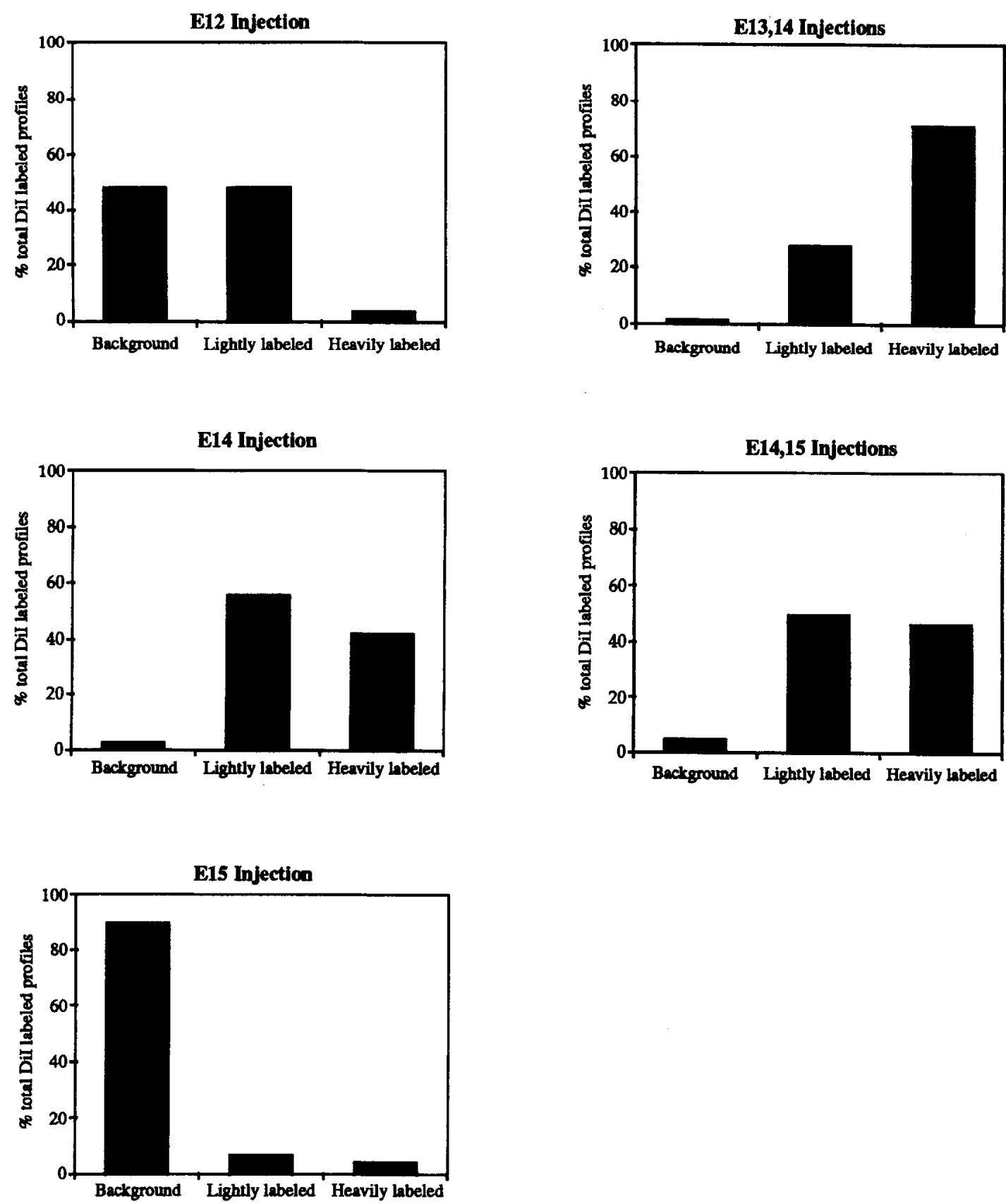

Figure 5. Percentages of DiI-labeled profiles considered to be labeled heavily, lightly, or at background levels by ${ }^{3} \mathrm{H}-\mathrm{TdR}$ injected at the ages indicated. For all injection cases, background was two or fewer silver grains over the DiI profile. The criterion for a heavily labeled profile was set at $25 \%$ of the number of silver grains over the most heavily labeled cell in that section. Since the sections were $1.5 \mu \mathrm{m}$ thick, a single nucleus $(\sim 6$ $\mu \mathrm{m}$ in diameter at E18) would be included in several plastic sections.

white matter near the midline (Fig. $6 B)$ of P0 rats $(n=8)$. The distribution of retrogradely labeled neurons observed at $\mathrm{P} 3$ was continuous across the tangential extent of cingulate cortex and neocortex (Fig. $6 A$ ), reflecting the early transient widespread distribution of callosal neurons prior to the period of axon elimination (Ivy and Killackey, 1981, 1982; O'Leary et al., 1981). In neocortical regions, large numbers of cells were labeled in layers 2-6 (Fig. 6C-F), consistent with previous findings that all of thesc layers send a callosal projection in developing and mature rats (Wise and Jones, 1976; Ivy and Killackey, 1981, 1982; O'Leary et al., 1981). However, cells in the neocortical subplate were rarely retrogradely labeled by the injections made into the contralateral cortex, indicating that a callosal projection from the subplate layer is, at most, a very minor onc. Ipsilateral and lateral to the injection site, large numbers of subplate cells are retrogradely labeled, indicating that the subplate extends a major axonal projection medially within a cortical hemisphere (Fig. 7).

It is unlikely that the indusium griseum, a midline structure overlying the corpus callosum and associated with the hippocampus, contains early callosal cells. Cells of the indusium griseum are not retrogradely labeled by contralateral cortical injections of FB, DY, or RB on P0 and usually not by our embryonic DiI injections. Indusium griseum cells were labeled, though, in 


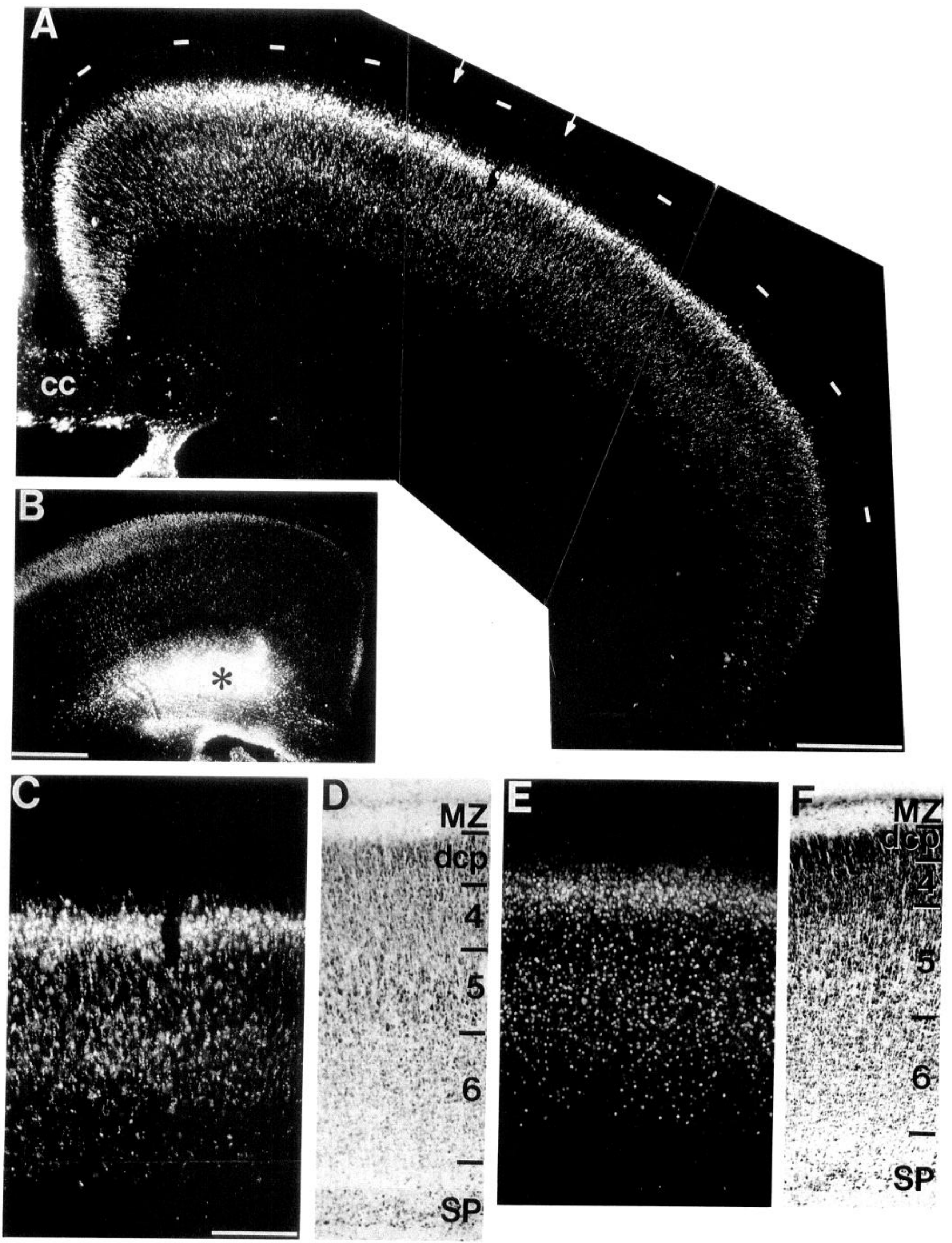



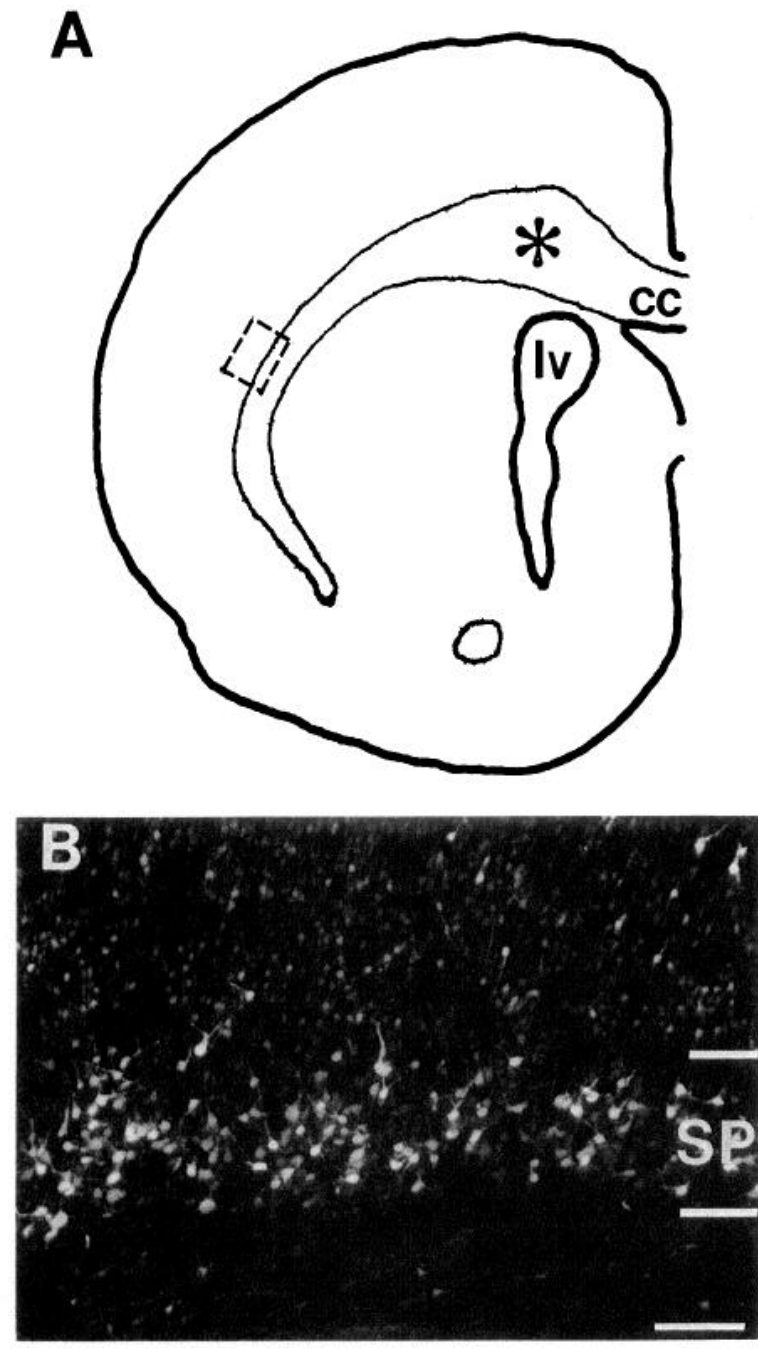

Figure 7. Neocortical subplate cells extend axons medially toward the midline corpus callosum. $A$, Schematic showing the location of a fast blue injection site in medial cortex (asterisk). The approximate location of $B$ is outlined. $B$, Cells in the neocortical subplate retrogradely labeled with fast blue from the injection shown in $A$. These cells must have axons extending medially to the injection site. This material is taken from the experimental case shown in Figure $6 A-D . c c$, corpus callosum; $l v$, lateral ventricle. Scale bar, $50 \mu \mathrm{m}$.

one E19 case in which DiI was injected very close to the midline. In this material, the indusium griseum cells appeared to be embedded in the callosal fiber bundle. In no cases in which DiI was injected later in development were indusium griseum cells retrogradely labeled.

\section{Does cingulate cortex have a subplate?}

A recent study of the generation of neurons in the cingulate cortex noted that this cortical region lacks a defined subplate
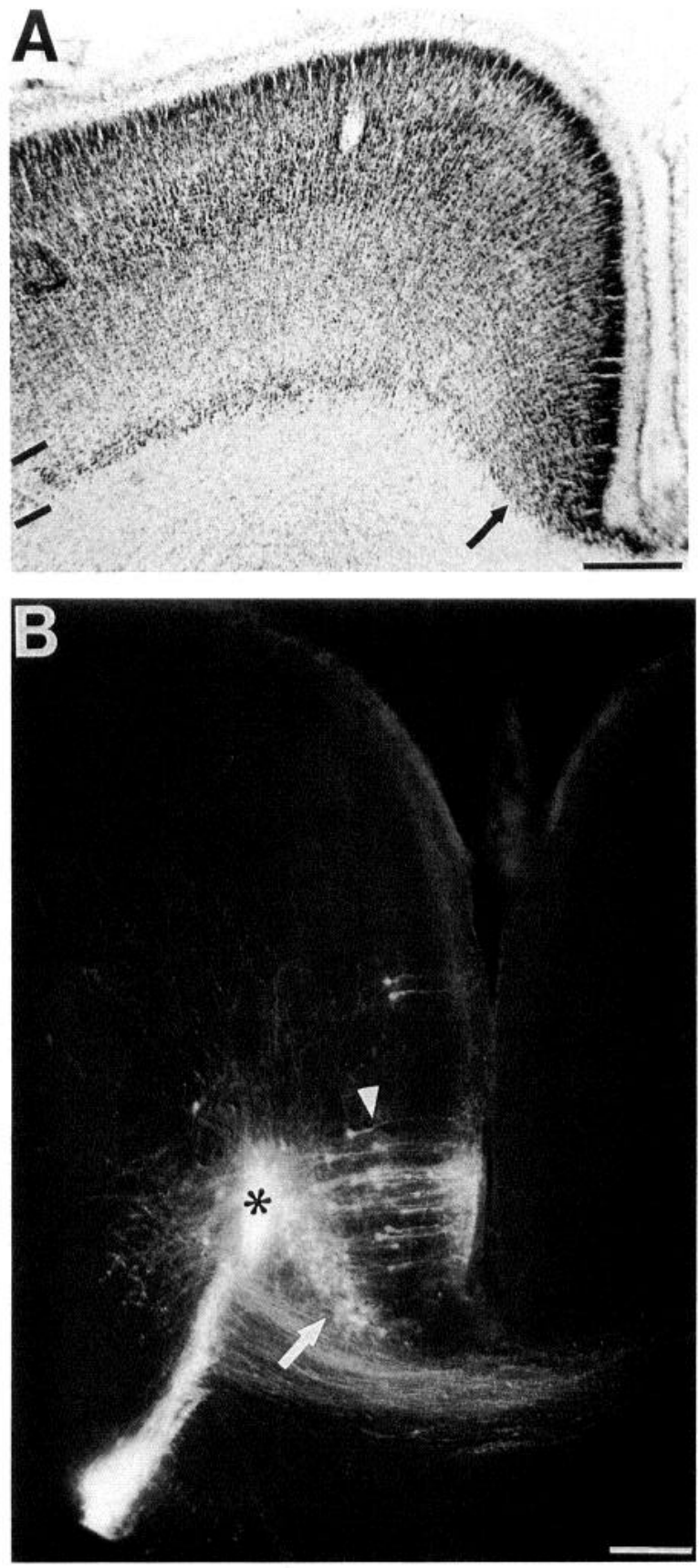

Figure 8 . The subplate of cingulate cortex. $A$, Nissl-stained section from a P3 rat. The subplate layer is continuous from the neocortex (lines) through to the most medial part of cingulate cortex (arrow). B, DiI injected on P0 in cingulate cortex (asterisk) retrogradely labels cingulate cortical cells medial to the injection site. Cells in the cortical plate (arrowhead) have the morphology of immature pyramidal cells; those in the "subplate" (arrow) resemble subplate neurons of the neocortex. Scale bars: $A, 250 \mu \mathrm{m} ; B, 100 \mu \mathrm{m}$.

Figure 6. Neocortical subplate neurons rarely project callosally. $A$, The pattern of retrograde labeling in contralateral cortex on P3 following an injection of, in this case, RB in the white matter of the medial cortex $(B)$. Dashed lines in $A$ mark the pial surface. Arrows in $A$ mark the region from which $C$ was taken. Callosal cells are evenly distributed throughout all regions of the neocortex at this age. $C$, Higher-magnification image of labeling shown in $A$. D. Nissl-stained adjacent section. No retrogradely labeled callosal cells are found in the subplate layer. $E$, Contralateral retrograde labeling from a similar case in which DY was injected into the contralateral hemisphere of cortex. $F$, Nissl-stained adjacent section. $M Z$, marginal zone; $d c p$, dense cortical plate; $S P$, subplate; $c c$, corpus callosum. Scale bars: $A$ and $B, 500 \mu \mathrm{m} ; C-F, 200 \mu \mathrm{m}$. 

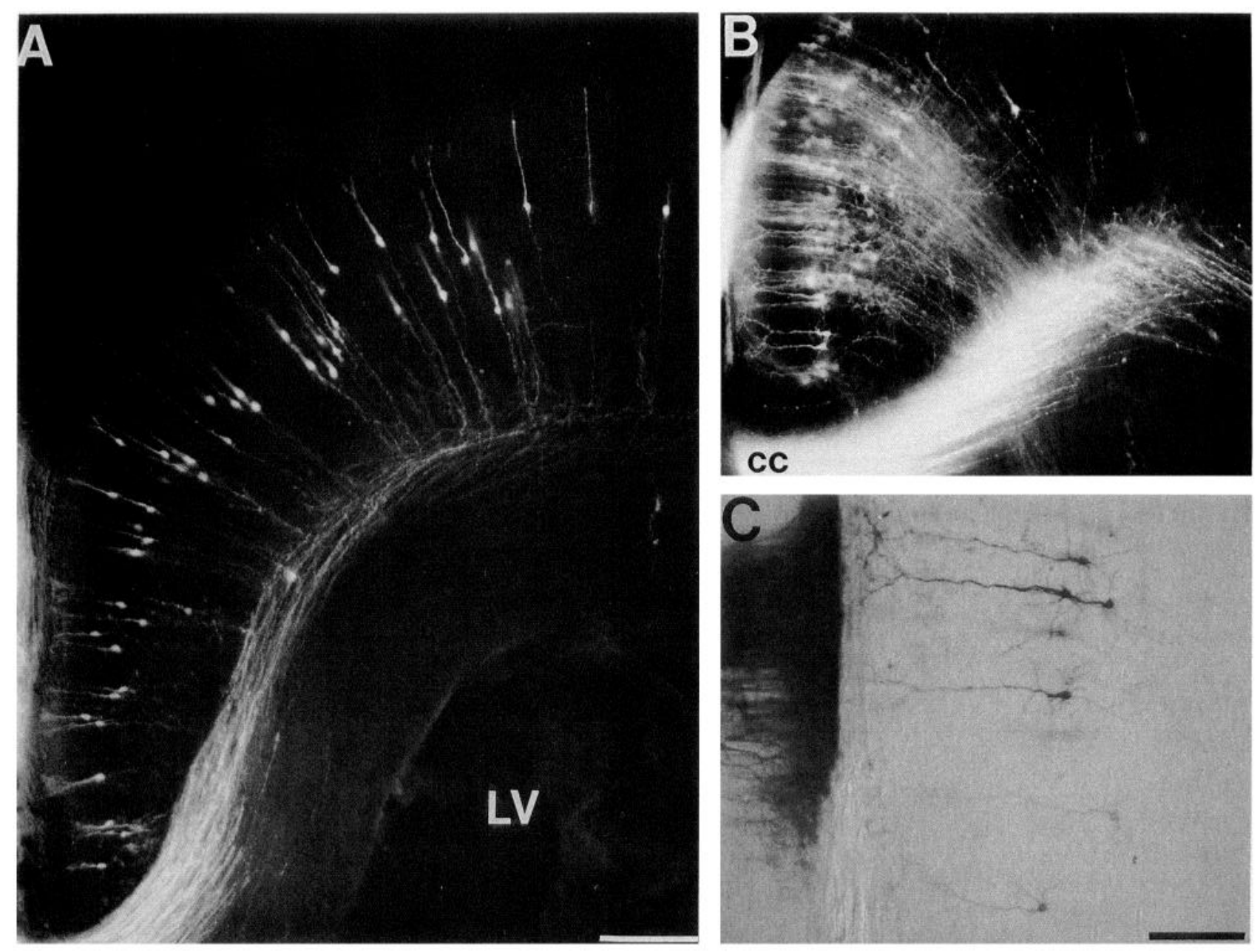

Figure 9. Morphologies of callosally projecting neurons in late embryonic and early postnatal cingulate cortex. Cells were retrogradely labeled with DiI placed in contralateral cingulate cortex in brains fixed on $\mathrm{E} 19(A), \mathrm{P} 0(B)$, or $\mathrm{P} 3(C)$. The cells shown in $C$ have been photoconverted in the presence of DAB. The morphologies are different from those seen at E18, and more closely resemble neocortical pyramidal neurons. Scale bars: $A, 300 \mu \mathrm{m} ; C, 150 \mu \mathrm{m}$.

layer (Bayer, 1990a). However, we find in Nissl-stained sections from developing rats that a continuous subplate layer is present from lateral neocortical regions to the most medial part of the cingulate cortex (Fig. $8 A$ ). Laterally in cingulate cortex, the subplate layer is very distinct deep to layer 6 of the cortical plate; in the most medial part of cingulate cortex, the subplate layer is still apparent, although less distinct as it comes to abut the overlying cortical plate. DiI injected into the cingulate cortex and the underlying white matter retrogradely labels cells in both the subplate and cortical plate medial to the injection site (Fig. $8 B$ ). In these cases, the subplate layer is clearly definable based on the morphological distinctions of the subplate neurons compared to the pyramid-shaped cells of the cortical plate. Similar to the paucity of labeling of neocortical subplate cells, few or no cells in the cingulate subplate are retrogradely labeled by tracer injections made into the contralateral cortex (Fig. 6A).

\section{Maturation of cingulate callosal neuron morphology}

To examine the morphology and distribution of callosally projecting neurons in cingulate cortex at later stages, DiI was injected into the white matter/intermediate zone underlying presumptive cingulate cortex in brains fixed on E19 $(n=5)$, E20 $(n=3), \mathrm{P} 0(n=3)$, or $\mathrm{P} 3(n=3)$. Representative labeling from the contralateral hemisphere is shown in Figure 9. The retrogradely labeled callosal neurons are predominantly found in the deep layers of the cortical plate and have pyramidal-like morphologies with radially aligned apical dendrites extending into layer 1. This morphology is typical of the pyramidal cells in the deep layers of mature cingulate cortex (Ramon y Cajal, 1922) and atypical of subplate cells in the same region. These findings suggest that the early callosal cingulate neurons mature into pyramidal neurons of the cingulate cortical plate.

\section{Discussion}

We have shown that the first cells to send axons across the corpus callosum are found in a small cluster in cingulate cortex. Although these cells are among the earliest generated in cingulate cortex, they are predominantly found in the cingulate cortical plate. They appear to mature into a classic pyramidal morphology, rather than horizontal, multipolar, or inverted pyramidal morphologies more typical of subplate neurons, and come to occupy the deep layers of cingulate cortex. Subplate neurons in neither neocortex nor cingulate cortex ever form a significant projection to contralateral cortex. Thus, unlike the cortical pro- 
jection through the internal capsule to subcortical targets, the other major cortical efferent pathway, the corpus callosum, is not pioneered by cells of the neocortical subplate, but instead by a discrete population of cingulate neurons.

\section{Phylogeny and ontogeny of the corpus callosum}

The corpus callosum was initially believed to be a lamina terminalis structure, having evolved from the anterior commissure, the pathway through which neocortical commissural axons cross in marsupial mammals (see Ebner, 1969, for a historical perspective). However, later comparative studies demonstrated that the corpus callosum develops free of the anterior commissure, instead splitting the primordial subiculum into the supracallosal indusium griseum and subcallosal subiculum, while creating a phylogenetically new pathway (Abbie, 1940; Ebner, 1969; Silver et al., 1982; Katz et al., 1983). This conclusion is supported by descriptions of mice (Wahlsten, 1984) and humans (Rakic and Yakovlev, 1968) with congenital deficiencies of the corpus callosum but a normal anterior commissure, suggesting that the corpus callosum and anterior commissure are also genetically distinct.

Two hypotheses have been put forward to explain the structural substrate for the phylogenetic and ontogenetic establishment of the corpus callosum. One hypothesis is that the hippocampal commissure provides a structural support for callosal axons at their midline crossing point. Early callosal fibers in both rats and mice initially extend across the midline in close proximity to fibers of the hippocampal commissure (Wahlsten, 1981; Valentino and Jones, 1982). However, electron microscopic studies show a layer of glial cells separating these two fiber bundles (Valentino and Jones, 1982), indicating that callosal axons do not grow directly upon the axons of the hippocampal commissure. This conclusion is consistent with the comparative observations of adult commissure structure by Abbie (1940), who argued that the callosal pathway is phylogenetically distinct from the hippocampal commissure, and that the proximity of these two structures in the developing rodent brain is coincidental.

An alternative hypothesis is that of the midline glial sling originally described in the mouse (Silver et al., 1982). These authors hypothesize that this structure spanning between the two hemispheres provides a mechanical support required for extension of callosal axons (Silver et al., 1982; but see Valentino and Jones, 1982). A recent study in cats using immunocytochemical markers of neurons and glia describes that a population of midline glia advance rostrally from the lamina terminalis, effectively "zipping together" the cerebral hemispheres, and slightly later the first callosal axons cross the midline of this glial sling (Silver et al., 1993). Thus, glia may be the first cellular elements of the corpus callosum, followed closely by axons. We find that the first cortical axons cross the midline of the corpus callosum in rats on $\mathrm{E} 17,1.5 \mathrm{~d}$ earlier than previously reported using other techniques (Valentino and Jones, 1982; Floeter and Jones, 1985), and are extended by cells in cingulate cortex. A later wave of migrating cells that also may be glia has been observed to migrate both laterally and medially from the dorsal cortical neuroepithelium toward the internal capsule on E17 and the corpus callosum on E20 (Altman and Bayer, 1990). However, this migration occurs about $3 \mathrm{~d}$ after cortical axons first extend through these pathways and therefore is not required for their establishment.

\section{Identity of the callosal pioneer neurons}

In contrast to a previous report (Bayer, 1990a), our evidence indicates that cingulate cortex has a subplate layer. Although the pioneering callosal neurons are among the earliest generated cells in cingulate cortex, most appear to be part of the cingulate cortical plate rather than subplate. This observation is consistent with our finding that few subplate cells of the neocortex ever extend axons across the corpus callosum. An alternative explanation of our findings is that the pioneering callosal cells retrogradely labeled on E18 are cingulatc subplate ncurons, but their callosal axons are rapidly removed through either cell death or axon elimination, and a different population of newly projecting callosal neurons are detected in cingulate cortical plate with retrograde labeling on E19 and later. Although we cannot rule out this scenario, we consider it unlikely for two reasons: first, subplate cell death has been extensively studied in rodents (Al-Ghoul and Miller, 1989; Valverde et al., 1989; Ferrer et al., 1990; Woo et al., 1991), as in other mammals (Luskin and Shatz, 1985a; Wahle and Meyer, 1987; Valverde and Facal-Valverde, 1988; Chun and Shatz, 1989; Kostovic and Rakic, 1990), and is described to begin on E20 in rats and continue over several days or weeks; second, axon elimination in the rat callosal projection (O'Leary et al., 1981; Ivy and Killackey, 1982) has been first detected on P5 and occurs over a 2 week period (Ivy and Killackey, 1981). Thus, as the evidence presently stands, both the onset and duration of both of these phenomena, cell death and axon elimination, are inappropriate to account for our observations. It should be noted, though, that callosal axon elimination has not been examined in embryonic rodents, and thus remains a possibility.

In neonatal rats callosally projecting neurons are found in all differentiated layers derived from the cortical plate, both in cingulate cortex and neocortex. However, the labeling in the subplate underlying the cortical plate in both cortical regions is exceptionally sparse, with few cells retrogradely labeled in each case examined. The apparent difference between our finding in rat and that of Chun et al. (1987), who report the presence of callosal cells in the feline subplate, may simply be a matter of emphasis due to the difference in aims of the two studies. A goal of the Chun et al. (1987) study was to determine if subplate cells extend long axons, and in this way provide definitive evidence that they are neurons. Even the small number of subplate cells that they identified to extend axons to contralateral cortex sufficed for this purpose. A goal of our study was to determine whether neocortical subplate cells extend the first axons across the corpus callosum, which they do not. Indeed, the callosal projection from the neocortical subplate is an insignificant projection when compared to the subcortical projection to thalamus from the same layer in ferrets, cals (Antonini and Shatz, 1990), and rats (De Carlos and O'Leary, 1992).

\section{Significance of callosal pioneers}

The concept of pioneer neurons has come from studies of invertebrate nervous systems (Bate, 1976; Goodman et al., 1984). In grasshoppers, pioneering sensory axons in the limb extend into the CNS at a stage when structures are closer together and the intervening substrate is less mature. Ablation of some of these pioneers disrupts the pathfinding of later growing sensory axons to the CNS (Klose and Bentley, 1989), whereas ablation of other sensory pioneers does not have this effect (Keshishian and Bentley, 1983). These findings demonstrate that in insects 
some pioneer neurons can serve a crucial role in later axon outgrowth, while others apparently do not. An important issue is whether or not pioneers of cortical efferent pathways are required for the proper development of later arising cortical efferent projections.

In developing mammals, neocortical subplate cells have been shown to pioneer the internal capsule (McConnell et al., 1989; Blakemore and Molnar, 1990; De Carlos and O'Leary, 1992; Erzurumlu and Jhaveri, 1992) and have been suggested to play a role in the establishment of the pathways that pass through it (Ghosh and Shatz, 1993; Allendoerfer and Shatz, 1994; McConnell et al., 1994). Examination of the morphologies of cortical axon growth cones as they extend through the internal capsule show that the earlier growth cones are more complex than those extending through the same pathway later in development. These results suggest that subplate axon growth cones navigate the pathway independently of one another, while the growth cones of later growing cortical plate axons (presumably extended by layer 5 and 6 neurons) fasciculate with the earlier subplate axons (Kim et al., 1991). Although early ablation of subplate cells does not prevent layer 5 and 6 axons from navigating the internal capsule, it does disrupt the development of layer 6 corticothalamic projections within thalamus (McConnell et al., 1994). In the corpus callosum, the growth cones of even later extending axons have complex morphologies (Norris and Kalil, 1990) and exhibit continuous filopodial exploration and changes in lamellopodial shape (Halloran and Kalil, 1994), suggesting that callosal axons navigate independently of one another. Future experiments will be necessary to determine if the pioneering cingulate axons serve a crucial role in the development of the corpus callosum.

A priori, one might expect that cingulate neurons pioneer the corpus callosum simply because they are closest to it. However, proximity seems not to be the sole determining factor. Indeed, subplate neurons in the neighboring neocortex are generated days before the callosal pioneers in cingulate cortex, and begin to extend long axons almost immediately; yet, neocortical subplate neurons do not send the first axons across the callosum, nor do they ever project through the corpus callosum in any significant number. On the other hand, axons extended by cortical plate neurons of the neocortex across the corpus callosum only lag by about a day or two those extended by cingulate cortical neurons. Thus, proximity may explain why cingulate neurons send axons through the corpus callosum before neurons in the neocortical cortical plate, but not before those in the neocortical subplate.

Since subplate neurons pioneer the internal capsule, one might ask why they do not pioneer the corpus callosum. One possible explanation derives from consideration of evolutionary data. The corpus callosum is a relatively new structure in cortical phylogeny, coming into existence only with the separation betwecn placental and marsupial mammals (Abbie, 1940; Katz et al., 1983). In contrast, connections from the cortex to subcortical targets presumably evolved coincident with the evolution of the cortex. Subplate cells are found in all mammalian species, placental, and marsupial (opossum: Saunders et al., 1989; mouse: Wood et al., 1992; hamster: Woo et al., 1991; rat: Valverde et al., 1989; Bayer and Altman, 1990; cat: Marin-Padilla, 1978; Luskin and Shatz, 1985a; primate: Kostovic and Rakic, 1990), and have been suggested (as a derivative of the preplate) to be a remnant of a primordial or reptilian cortex (Marin-Padilla, 1978). Thus, subplate may have evolved its functions, including that of pioneering pathways, prior to the evolution of the dorsally located cortical commissure, the corpus callosum. Since the callosal pathway develops phylogenetically and ontogenetically later than the subcortical pathway, the cues necessary for axon extension along the callosal trajectory maybe overlaid on the phylogenetically older cues for subcortical axon extension.

What might be the nature of these cues? One possibility is the action of chemotropic substances emitted by the cells of the glial sling. Diffusible cues are known to play a role in target selection by trigeminal ganglion cells (Lumsden and Davies, 1983) and by subcortically projecting layer 5 cortical axons (Heffner et al., 1990). Perhaps more relevant, though, is the demonstration that a diffusible activity released by a midline structure, the floor plate, influences spinal commissural axons to deviate toward their midline crossing point (Tessier-Lavigne et al., 1988). Whether diffusible or local guidance cues direct callosal axon growth, it would appear that the callosal guidance cue is expressed in a temporally regulated manner along the pathway of callosal axons such that their medially directed extension is not promoted or perhaps even permitted until later in corticogenesis. This scenario is suggested by the late development of the corpus callosum relative to the internal capsule, and is strongly implied by the observation that the early extension of axons in cortex is polarized laterally toward the internal capsule; only at later stages do cortical axons begin to extend medially along the callosal trajectory (Koester et al., 1992). These observations, taken with the demonstration that the two major efferent projections from neocortex, the callosal and the subcortical, arc formed by distinct populations of projection neurons (Koester and O'Leary, 1993), indicate that these two neuronal populations respond in distinct ways to cues found in their common environment. Similar mechanisms may be responsible for imparting the developmental and spatial distinctions between the populations of neurons that pioneer the two major output pathways of the mammalian cortex.

\section{References}

Abbie, AA (1940) The origin of the corpus callosum and the fate of the structures related to it. J Comp Neurol 72:9-44.

Al-Ghoul WM, Miller MW (1989) Transient expression of Alz-50 immunoreactivity in developing rat neocortex: a marker for naturally occurring neuronal death? Brain Res 481:361-367.

Allendoerfer KL, Shatz CJ (1994) The subplate, a transient neocortical structure: its role in the development of connections between thalamus and cortex. Annu Rev Neurosci 17:185-218.

Altman J, Bayer SA (1990) Horizontal compartmentation in the germinal matrices and intermediate zone of the embryonic rat cerebral cortex. Exp Neurol 107:36-47.

Angevine JB Jr, Sidman RL (1961) Autoradiographic study of cell migration during histogenesis of cerebral cortex in the mouse. Nature 192:766-768.

Antonini A, Shatz SJ (1990) Relation between putative transmitter pheontypes and connectivity of subplate neurons during cerebral cortical development. Eur J Neurosci 2:744-761.

Bate CM (1976) Pioneer neurons in an insect embryo. Nature 260: 54-56.

Bayer SA (1990a) Development of the lateral and medial limbic cortices in the rat in relation to cortical phylogeny. Exp Neurol 107:118131.

Bayer SA (1990b) Neurogenetic patterns in the medial limbic cortex of the rat related to anatomical connections with the thalamus and striatum. Exp Neurol 107:132-142.

Bayer SA, Altman J (1990) Development of layer 1 and the subplate in the rat neocortex. Exp Neurol 107:48-62.

Bentley D, Keshishian H (1982) Pioneer neurons and pathways in insect appendages. Trends Neurosci 5:354-358. 
Berry M, Rogers AW (1965) The migration of neuroblasts in the developing cerebral cortex. J Anat 99:691-709.

Blakemore C, Molnar Z (1990) Factors involved in the establishment of specific interactions between thalamus and cerebral cortex. Cold Spring Harbor Symp Quant Biol 55:491-504.

Bruckner G, Mares V, Bieshold D (1976) Neurogenesis in the visual system of the rat. an autoradiographic investigation. J Comp Neurol 166:245.

Catsman-Berrevoets CE, Lemon RN, Verburgh CA, Bentivoglio M, Kuypers HGJM (1980) Absence of callosal collaterals derived from rat corticospinal neurons. Exp Brain Res 39:433-440.

Chun JJM, Shatz CJ (1989) Interstitial cells of the adult neocortical white matter are the remnant of the early generated subplate neuron population. J Comp Neurol 282:555-569.

Chun JJM, Nakamura MJ, Shatz CJ (1987) Transient cells of the developing mammalian telencephalon are peptide-immunoreactive neurons. Nature 325:617-620.

Cowan WM, Gottlieb DI, Hendrickson AE, Price JL, Woolsey TA (1972) The autoradiographic demonstration of axonal connections in the central nervous system. Brain Res 37:21-51.

DeCarlos JA, O'Leary DDM (1992) Growth and targeting of subplate axons and establishment of major cortical pathways. J Neurosci 12: $1194-1211$.

Ebner FF (1969) A comparison of primitive forebrain organization in metatherian and eutherian mammals. Ann NY Acad Sci 167:241257.

Erzurumlu RS, Jhaveri S (1992) Emergence of connectivity in the embryonic rat parietal cortex. Cereb Cortex 2:336-352.

Ferrer I, Bernet E, Soriano E, Del Rio T, Fonseca M (1990) Naturally occurring cell death in the cerebral cortex of the rat and removal of dead cells by transitory phagocytes. Neuroscience $39: 451-458$.

Floeter MK, Jones EG (1985) The morphology and phased outgrowth of callosal axons in the fetal rat. Dev Brain Res 22:7-18.

Ghosh A, Shatz CJ (1993) A role for subplate neurons in the patterning of connections from thalamus to neocortex. Development 117:10311047.

Godement P, Vanselow J, Thanos S, Bonhoeffer F (1987) A study in developing visual systems with a new method of staining neurones and their processes in fixed tissue. Development 101:697-713.

Goodman CS, Bastiani MJ, Doe CQ, du Lac S, Helfand SL, Kuwada JY, Thomas JB (1984) Cell recognition during neuronal development. Science 225:1271-1279.

Halloran MC, Kalil K (1994) Dynamic behaviors of growth cones extending in the corpus callosum of living cortical brain slices observed with video microscopy. J Neurosci 14:2161-2177.

Heffner CD, Lumsden AGS, O'Leary DDM (1990) Target control of collateral extension and directional axon growth in the mammalian brain. Science 247:217-220.

Honig MG, Hume RI (1989) DiI and DiO: versatile fluorescent dyes for neuronal labeling and pathway tracing. Trends Neurosci 12:333341.

Ivy GO, Killackey HP (1981) The ontogeny of the distribution of callosal projection neurons in the rat parietal cortex. J Comp Neurol 195:367-389.

Ivy GO, Killackey HP (1982) Ontogenetic changes in the projections of neocortical neurons. J Neurosci 2:735-743

Katz MJ, Lasek RJ, Silver J (1983) Ontophyletics of the nervous system: development of the corpus callosum and evolution of axon tracts. Proc Natl Acad Sci USA 80:5936-5940.

Keshishian H, Bentley D (1983) Embryogenesis of peripheral nerve pathways in grasshopper legs. III. Development without pioneer neurons. Dev Biol 96:116-124.

Kim GJ, Shatz CJ, McConnell SK (1991) Morphology of pioneer and follower growth cones in the developing cerebral cortex. J Neurobiol 22:629-642.

Klose M, Bentley D (1989) Transient pioneer neurons are essential for formation of an embryonic peripheral nerve. Science 245:982984.

Koester SE, O'Leary DDM (1991) Subplate cells in medial cortex send the first axons across the corpus callosum. Soc Neurosci Abstr 17:41.

Koester SE, O'Leary DDM (1993) Connectional distinction between callosal and subcortically projecting cortical neurons is determined prior to axon extension. Dev Biol 160:1-14.

Koester SE, Lucidi-Phillipi CA, O'Leary DDM (1992) Regional po- larization of early axon extension by cortical neurons. Soc Neurosci Abstr 18:223.

Kostovic I, Rakic P (1990) Developmental history of the transient subplate zone in the visual and somatosensory cortex of the macaque monkey and human brain. J Comp Neurol 297:441-470.

Lumsden AGS, Davies AM (1983) Earliest sensory nerve fibers are guided to peripheral targets by attractants other than nerve growth factor. Nature 306:786-788.

Lund RD, Mustari MJ (1977) Development of the geniculocortical pathway in rats. J Comp Neurol 173:289-306.

Luskin MB, Shatz CJ (1985a) Studies of the earliest generated cells of the cat's visual cortex: cogeneration of subplate and marginal zones. J Neurosci 5:1062-1075.

Luskin MB, Shatz CJ (1985b) Neurogenesis of the cat's primary visual cortex. J Comp Neurol 242:611-631.

Marin-Padilla M (1978) Dual origin of the mammalian neocortex and the evolution of the cortical plate. Anat Embryol (Berl) 152:109-126.

McConnell SK, Ghosh A, Shatz CJ (1989) Subplate neurons pioneer the first axon pathway from the cerebral cortex. Science 245:978982.

McConnell SK, Ghosh A, Shatz CJ (1994) Subplate pioneers and the formation of descending connections from cerebral cortex. J Neurosci 14:1892-1907.

Miller R (1975) Distribution and properties of commissural and other neurons in cat sensorimotor cortex. J Comp Neurol 164:361-374.

Norris CR, Kalil K (1990) Morphology and cellular interactions of growth cones in the developing corpus callosum. J Comp Neurol 293: 268-281.

O'Leary DDM, Stanfield BB, Cowan WM (1981) Evidence that the early postnatal restriction of the cells of origin of the callosal projection is due to the elimination of axonal collaterals rather than to the death of neurons. Dev Brain Res 1:607-617.

Rakic P (1974) Neurons in rhesus monkey visual cortex: systematic relation between time of origin and eventual disposition. Science 183: 425-427.

Rakic P, Yakovlev PI (1968) Development of the corpus callosum and cavum septi in man. J Comp Neurol 132:45-72.

Ramon y Cajal S (1922) Estudios sobre la fina cstructura de la cortcza regional de los roedores. Trab Lab Invest Biol Univ Madrid 20:130.

Richter W, Kranz D (1979) Autoradiographische Untersuchungen zur Neurogenese und Morphogenese der Regio cingularis der Ratte. IV. Quantitative Untersuchungen zur Ermittlung der Zellursprungszeiten der Cortexschichten. J Hirnforsch 20:581-629.

Rogers AW (1979) Techniques of autoradiography. Amsterdam: Elsevier.

Sandell JH, Masland RH (1988) Photoconversion of some fluorescent markers to a diaminobenzidine reaction product. J Histochem $\mathrm{Cy}$ tochem 36:555-559.

Saunders NR, Adam E, Reader M, Mollgard K (1989) Monodelphis domestica (grey short-tailed opossum): an accessible model for studies of early neocortical development. Anat Embryol (Berl) 180:227-236.

Silver J, Lorenz SE, Wahlsten D, Coughlin J (1982) Axonal guidance during development of the great cerebral commissures: descriptive and experimental studies, in vivo, on the role of preformed glial pathways. J Comp Neurol 210:10-29.

Silver J, Edwards MA, Levitt P (1993) Immunocytochemical demonstration of early appearing astroglial structures that form boundaries and pathways along axon tracts in the fetal brain. J Comp Neurol 328:415-436.

Swadlow HA, Weyand TG (1981) Efferent systems of the rabbit visual cortex: laminar distribution of the cells of origin, axonal conduction velocities and identification of axonal branches. J Comp Ncurol 203 . 799-822

Tessier-Lavigne M, Placzek M, Lumsden AGS, Dodd J, Jessell TM (1988) Chemotropic guidance of developing axons in the mammalian central nervous system. Nature 336:775-778.

Valentino KL, Jones EG (1982) The early formation of the corpus callosum: a light and electron microscopic study in foetal and neonatal rats. J Neurocytol 11:583-609.

Valverde F, Facal-Valverde MV (1988) Postnatal development of interstitial (subplate) cells in the white matter of the temporal cortex of kittens: a correlated Golgi and electron microscopic study. J Comp Neurol 269:168-192.

Valverde F, Facal-Valverde MV, Santacana M, Heredia M (1989) De- 
velopment and differentiation of early generated cells of sublayer VIb in the somatosensory cortex of the rat: a correlated Golgi and autoradiographic study. J Comp Neurol 290:118-140.

Wahle P, Meyer G (1987) Morphology and quantitative changes of transient NPY-ir neuronal populations during early postnatal development of the cat visual cortex. J Comp Neurol 261:165-192.

Wahlsten D (1981) Prenatal schedule of appearance of mouse brain commissures. Dev Brain Res 1:461-473.

Wahlsten D (1984) Growth of the mouse corpus callosum. Dev Brain Res 15:59-67.

Wise SP, Jones EG (1976) The organization and postnatal development of the commissural projection of the rat somatic sensory cortex. J Comp Neurol 168:313-344.
Wise SP, Jones EG (1977) Cells of origin and terminal distribution of descending projections of the rat somatic sensory cortex. J Comp Neurol 175:129-158

Wong D, Kelly JP (1981) Differentially projecting cells in individual layers of the rat auditory cortex: a double-labeling study. Brain Res 230:362-366.

Woo TU, Beale JM, Finlay RL (1991) Dual fate of subplate neurons in a rodent. Cereb Cortex 1:433-443.

Wood JG, Martin S, Price DJ (1992) Evidence that the earliest generated cells of the murine cerebral cortex form a transient population in the subplate and marginal zone. Dev Brain Res 66:137-140. 